\title{
Accounting
}

homepage: www.GrowingScience.com/ac/ac.html

\section{The effect of tax revenues on GDP growth in Jordan}

\author{
Khaled Abdalla Moh'd AL-Tamimi ${ }^{a^{*}}$ and Ashraf Bataineh ${ }^{a}$
}

${ }^{a}$ Department of Financial and Administrative Sciences, Irbid University College, Al-Balqa' Applied University, Jordan

\begin{tabular}{l} 
C H R O N I C L E \\
\hline Article history: \\
Received: October 29, 2020 \\
Received in revised format: \\
November 272020 \\
Accepted: December 15, 2020 \\
Available online: \\
December 15, 2020 \\
\hline Keywords: \\
Tax Revenue \\
Growth of gross domestic product \\
Financial resources \\
Investments
\end{tabular}

\section{Introduction}

All countries aim to increase the financial resources they obtain in order to adhere to the financial and public burdens and expenditures that they undertake in order to achieve the required economic and social development, and countries use all methods and means through which to increase revenues, and the most important of these methods is tax, since tax revenues are the most important sources of income in many countries of the world, especially in developing countries (Narayan, 2005). Taxes are used as one of the most important financial policy tools through which the state can influence the existing economic, social and commercial activities within the state, which are considered as one of the main sources of tax revenue. Jordan is interested in tax laws and legislation, since it has used a set of financial policies and reforms with the aim of improving the state's public revenues and reducing tax evasion rates, as tax revenues are one of the most important sources of income on which the Jordanian economy depends mainly.

Jordan suffers from many financial problems and a continuous deficit in its budget, which has led to the need to work on finding ways through which to increase the revenues that the state obtains in order to reduce the deficit in the budget and tax revenues are the main source of income for the Jordanian government, which led to the necessity of work to improve the tax laws and

* Corresponding author.

E-mail address: khaled tamimi@yahoo.com (K. A. M. AL-Tamimi) 
legislations used and to upgrade the level of tax services provided to individuals and public and private companies in order to increase the tax revenues obtained. The problem of the study is to identify the effect of tax revenues on the growth of GDP in Jordan during the period (2000-2018), which is the period in which Jordan improved tax laws and legislation and granted tax exemptions to foreign investors in order to expand investment projects in Jordan.

The importance of the study is that it seeks to identify the impact of tax revenues on the growth of the gross domestic product in Jordan during the period (2000-2018), and it is one of the topics that has not been discussed significantly in scientific studies and research, which makes it one of the first studies and research dealt with this topic. In addition to the Scientific Economic Library, it contributes to opening the way for researchers and scholars to learn about the impact of tax revenues on achieving development in all economic sectors. The research aims to achieve a major goal, which is to study the effect of tax revenues on the growth of GDP in Jordan during the period (2000-2018) by achieving a set of sub-goals, namely:

1- Learn about research terminology and concepts related to the subject of study,

2- Study the development of tax revenues in Jordan during the study period,

3- Study the development of the gross domestic product in Jordan during the study period,

4- Reaching out to recommendations and proposals that can be used to achieve economic development in Jordan.

In order to achieve the objectives of the study, it is assumed that there is a statistically significant effect of tax revenues on the growth of GDP in Jordan during the period (2000-2018). The research uses some descriptive approach to identify the economic variables that are the subject of the study. The research will also use the standard analytical approach in order to analyze the research data through the use of the E-views program to reach results and recommendations that can be used. The study will use the data that will be obtained through reports and bulletins issued by the Central Bank of Jordan and the World Bank during the study period (2000-2018). The following summarizes the necessary terms and concepts of the proposed study.

Taxes: It is a monetary obligation imposed by the state on individuals compulsorily and without charge, according to the ability of the taxpayers to provide for the state's expenses and bear the financial burden (Ben Korda, 2017, p.6)

Tax revenue: They are the revenues that the state obtains through its sovereignty over individuals and local and foreign public and private companies that operate within the state. (Nazmi, 2015, p.150)

Gross domestic product (GDP): It is the monetary value of all final goods and services produced in an economy during a certain period of time, often a year. (Shawky, 2017, pp. 206-207)

\section{Literature reviews}

Agha (2005) studied the effect of taxes on the GDP in Sudan during the period (1981-2003), which aimed to identify the effect of taxes on creating sustainable development in Sudan. The study used some time series analysis method to test the study hypotheses. The study reached a set of results including that the tax system used in Sudan did not positively affect the GDP and led to the occurrence of many tax problems and to an increase in tax evasion rates. The study recommended the necessity of implementing a tax system that is consistent with the development goals that the government seeks to achieve (Agha, 2005). Nawasrah (2019) studied the impact of tax revenues on the growth of GDP in Jordan for the period 1992-2017, which aimed to measure the effect of tax revenues on the growth of GDP in Jordan. The study used a multiple linear regression model to test the hypotheses of the study. The results concluded the existence of a statistically significant impact of the sales tax and the customs tax on the growth of the GDP. The study recommended the necessity of working on improving tax services and focusing on indirect taxes such as customs taxes on imported goods that have analogous local products (Nawasrah, 2019) where the effects of indirect and direct taxes were different. While the indirect tax has a positive impact and promotes the economic growth of Vietnam, the effect of the direct tax was visible Nguyen (2019). The study aimed at identifying the role of government spending in achieving economic growth during the period (2010-2019). The study concluded that there was a slight effect of government expenditure and tax revenues as a percentage of the GDP on the Jordanian economy during the study period. The recommendation of the study was to learn more about other economic variables most affecting the Jordanian economy (Al-Tamimi, 2020; Pesaran \& Shin, 1998). There were six groups of factors that have significant impacts on tax compliance among Vietnamese SMEs. The paper recommended that tax agencies should help SMEs improve their accounting skills and increase their knowledge (Le et al. 2020). The voluntary tax compliance in another study was directly affected by the three factors of corporate reputation, business ownership, and audit probability (Pham et al., 2020).

\section{Applied framework}

The research aims to identify the impact of tax revenues on the growth of the GDP in Jordan during the period (2000-2018), and in order to achieve this goal the development of tax revenues and the development of the GDP will be studied during the study 
period, and the standard relations between the independent variable will also be studied. (The value of tax revenues) and the dependent variable (the value of the gross domestic product) during the study period.

3.1. The evolution of the value of tax revenues, the value of the gross domestic product in Jordan during the period (2000-2018)

Development of the value of tax revenues in Jordan during the period (2000-2018)

According to Table 1, we learn that the value of tax revenues in Jordan during the period 2000-2018 ranged between a minimum of 1.140 billion dinars in 2000 , and a maximum of 4.536 billion dinars in 2018 , and an annual average during the study period of 2.857 billion dinars, at a rate of an increase of $9.2 \%$ during the study period.

Development of the value of the gross domestic product in Jordan during the period (2000-2018):

According to Table 1, it was found that the value of the GDP in Jordan during the period (2000-2018) ranged between a minimum of 6.083 billion dinars in 2000, and a maximum of 29.894 billion dinars in 2018 and an annual average during the study period 17.151 billion dinars And an increase rate of $23.1 \%$ during the study period.

Table 1

The value of tax revenues and the value of GDP in Jordan during the period (2000-2018)

\begin{tabular}{|c|c|c|}
\hline Years & $\begin{array}{l}\text { the value of tax revenue } \\
\text { (Billion dinars) }\end{array}$ & $\begin{array}{l}\text { the value of gross domestic product } \\
\text { (Billion dinars) }\end{array}$ \\
\hline 2000 & 1.140 & 6.083 \\
\hline 2001 & 1.189 & 6.453 \\
\hline 2002 & 1.188 & 6.889 \\
\hline 2003 & 1.317 & 7.330 \\
\hline 2004 & 1.699 & 8.204 \\
\hline 2005 & 2.179 & 9.051 \\
\hline 2006 & 2.621 & 10.825 \\
\hline 2007 & 2.995 & 12.302 \\
\hline 2008 & 2.758 & 15.812 \\
\hline 2009 & 2.880 & 17.149 \\
\hline 2010 & 2.986 & 19.025 \\
\hline 2011 & 3.062 & 20.764 \\
\hline 2012 & 3.351 & 22.273 \\
\hline 2013 & 3.652 & 24.186 \\
\hline 2014 & 4.037 & 25.794 \\
\hline 2015 & 4.096 & 27.011 \\
\hline 2016 & 4.254 & 27.830 \\
\hline 2017 & 4.343 & 28.903 \\
\hline 2018 & 4.536 & 29.984 \\
\hline
\end{tabular}

Source:

$\checkmark \quad$ The Jordanian Ministry of Finance during the period (2000-2018)

$\checkmark \quad$ The Central Bank of Jordan during the period (2000-2018)

$\checkmark \quad$ https://data.albankaldawli.org/country/jordan

3.2 The Standard Model of the Relationship between Tax Revenues and the Gross Domestic Product in Jordan during the period (2000-2018)

In order to study and analyze the relationship between tax revenues and GDP in Jordan during the period (2000-2018), a number of standard tests were used. The developed Dickey-Fuller test (ADF) (Dickey \& Fuller, 1979) and the joint integration test were used to test the relationship between variables and test the number of periods of time slowdown. A vector error correction model was used to find out the type of relationship between the variables in the long- and short-term using E-views program.

\section{Unit root test}

To measure the stability of the model variables, the developed Dickey - Fuller test (ADF) was used and it was found from Table 2 that both the tax revenue series (X) and the GDP series (Y) were not stable at their level, and the stability occurred after taking the second difference, thus the two series became complementary. Of the second degree, and since the two strings are complementary at the same degree, the cointegration of ARDL is used to perform the covariance test between them.

Table 2

Dickey-Fuller developed test results (ADF)

\begin{tabular}{|c|c|c|c|c|c|c|c|c|c|}
\hline \multirow{2}{*}{ Variables } & \multicolumn{3}{|c|}{ Level } & \multicolumn{3}{|c|}{$1^{\text {st }}$ Difference } & \multicolumn{3}{|c|}{$2^{\text {nd }}$ Difference } \\
\hline & $\mathrm{ADF}$ & Sig. & Result & $\mathrm{ADF}$ & Sig. & Result & ADF & Sig. & Result \\
\hline $\mathrm{X}$ & 1.449 & 0.957 & NO stationary & -1.697 & 0.084 & NO Stationary & -5.079 & 0.000 & Stationary \\
\hline $\mathrm{Y}$ & 0.080 & 0.694 & No stationary & -0.330 & 0.550 & NO Stationary & -7.739 & 0.000 & Stationary \\
\hline
\end{tabular}


When performing the cointegration test, we find that there is no co-integration between the two series at 0.05 significance level.

Table 3

Cointegration Test

\begin{tabular}{lrrrl}
\hline \multicolumn{5}{c}{ Null Hypothesis: No levels relationshipF-Bounds Test } \\
\cline { 3 - 5 } $\mathrm{I}(1)$ & $\mathrm{I}(0)$ & Signif. & Value & Test Statistic \\
\hline & Asymptotic: $\mathrm{n}=1000$ & & & \\
& 3.02 & $10 \%$ & 1.420125 & F-statistic \\
4.16 & 3.62 & $5 \%$ & 1 & $\mathrm{~K}$ \\
4.79 & 4.18 & $2.5 \%$ & & \\
5.58 & 4.94 & $1 \%$ & & \\
\hline
\end{tabular}

Test the number of time slowdown periods

It can be seen from Table 4 that the optimum number of periods of slowdown is two time periods for the dependent variable (Y) and for the independent variable $(\mathrm{X})$.

Table 4

Time lag periods test

\begin{tabular}{|c|c|c|c|c|}
\hline Variable & Coefficient & Std. Error & t-Statistic & Prob. ${ }^{*}$ \\
\hline $\mathrm{Y}(-1)$ & 1.319285 & 0.29695 & 4.442783 & 0.001 \\
\hline$Y(-2)$ & -0.39129 & 0.235683 & -1.66024 & 0.1251 \\
\hline $\mathrm{X}$ & -1.561167 & 0.906136 & -1.722883 & 0.1129 \\
\hline $\mathrm{X}(-1)$ & 3.968844 & 1.389469 & 2.856375 & 0.0156 \\
\hline $\mathrm{X}(-2)$ & -1.874064 & 1.19864 & -1.563492 & 0.1462 \\
\hline $\mathrm{C}$ & 0.51496 & 0.534953 & 0.962627 & 0.3564 \\
\hline R-squared & 0.997168 & \multicolumn{2}{|c|}{ Mean dependent var } & 18.43129 \\
\hline Adjusted R-squared & 0.995881 & \multicolumn{2}{|c|}{ S.D. dependent var } & 8.162135 \\
\hline S.E. of regression & 0.523865 & \multicolumn{2}{|c|}{ Akaike info criterion } & 1.815398 \\
\hline Sum squared resid & 3.018776 & \multicolumn{2}{|c|}{ Schwarz criterion } & 2.109473 \\
\hline Log likelihood & -9.430879 & \multicolumn{2}{|c|}{ Hannan-Quinn criter. } & 1.844629 \\
\hline F-statistic & 774.618 & \multicolumn{2}{|c|}{ Durbin-Watson stat } & 2.087505 \\
\hline Prob(F-statistic) & 0 & & & \\
\hline
\end{tabular}

*Note: p-values and any subsequent tests do not account for model

\section{The error-correcting vector model for the long-term and short-term relationship}

In order to determine the value of the relationship parameters in the long and short run, it requires the necessity to estimate the error correction vectors, and it can be seen from Table 5 that the error limit correction factor reached its value of 0.072006 , which is significant at 0.05 level of significance, meaning that there is a correction from the short term to the long term at a speed of 0.072006 while the equation indicates In the long term, there is an effect of the correction in the long run because $\mathrm{X}$ is significant at 0.01 level of significance

Table 5

Results of error correction vector test

ECM Regression

Case 2: Restricted Constant and No Trend

\begin{tabular}{|c|c|c|c|c|}
\hline Variable & Coefficient & Std. Error & t-Statistic & Prob. \\
\hline $\mathrm{D}(\mathrm{X}(-1))$ & 1.874064 & 0.840557 & 2.229549 & 0.0476 \\
\hline CointEq(-1)* & -0.072006 & 0.03209 & -2.243878 & 0.0464 \\
\hline R-squared & 0.634912 & Mean dependent var & & 1.384176 \\
\hline Adjusted R-squared & 0.550661 & S.D. dependent var & & 0.718881 \\
\hline S.E. of regression & 0.481885 & Akaike info criterion & & 1.580103 \\
\hline Sum squared resid & 3.018776 & Schwarz criterion & & 1.776154 \\
\hline
\end{tabular}

* p-value incompatible with t-Bounds distribution. 
In order to know the effect of tax revenues on the GDP in Jordan during the period (2000-2018), a simple regression equation was calculated between the value of tax revenues (the independent variable) and the value of the GDP in Jordan (the dependent variable) during the period (2000-2018) and the results were as Follows:

Table 6 shows the significance of the model as a whole, as the value of $\mathrm{F}$ was significant at the level of 0.01 . It also became clear that the variables included in the model explain $93.4 \%$ of the changes that occur in the value of the GDP in Jordan during the period (2000-2018), while the rest of the changes are due to factors which were not included in the form used. It was found that there was a statistically significant effect of tax revenues on the GDP in Jordan during the period (2000-2018) at a significant level of 0.01 , which indicates the validity of the study hypothesis and the relationship between the two variables was a direct relationship and it has become clear that the greater the value of tax revenues by one unit, the greater the value of the GDP. The value of 7.257 indicates a positive impact of tax revenues on the growth and increase of the GDP in Jordan during the study period.

\section{Table 6}

The impact of tax revenues on the gross domestic product in Jordan during the period (2000-2018)

\begin{tabular}{ccccc}
\hline P-VALUE & $\mathrm{R}^{2}$ & $\mathrm{~F}$ & $\mathrm{~T}$ & $\mathrm{~B}$ \\
\hline 0.000 & 0.934 & $242.20 * *$ & $15.56 * *$ & 7.257
\end{tabular}

\footnotetext{
** Significance at 0.01 level
}

\section{Results}

$>$ Whenever the value of tax revenues increases by one unit, the value of GDP in Jordan increases by 7.257 units during the period (2000-2018).

$>$ The existence of a positive impact of tax revenues on the growth and increase of the GDP in Jordan during the period (2000-2018).

$>$ There is no common integration between tax revenues and gross domestic product in Jordan during the period (20002018).

$>$ There is a correction from the short term to the long term, and there is an effect of the long-term correction of the relationship between tax revenues and GDP during the period (2000-2018).

\section{Recommendations}

$>$ The necessity of working to facilitate the procedures for individuals to pay their taxes through modern technological means,

$>$ Working to develop and simplify tax services and raise the level of transparency in tax dealings with all individuals,

$>$ The necessity of making amendments to the tax law in order to be compatible with the living conditions of individuals and achieve the highest possible efficiency in collecting the taxes due,

$>$ Increasing the tax exemptions that are offered to foreign investment to encourage it to increase its investments in all economic, commercial, service and industrial fields in Jordan,

$>$ Working to diversify sources of income for the Jordanian economy and not to rely entirely on tax revenues as a primary source of income.

\section{References}

Al-Agha, M.J. (2005). The Impact of Taxes on the Gross Domestic Product in Sudan during the Period (1981-2003), Master Thesis, Department of Economics, College of Graduate Studies, Sudan University of Science and Technology. http://repository.sustech.edu/handle/123456789/8994?show=full

Al-Tamimi, K.A. M. (2020). Government spending as a tool for economic growth in the economy of Jordan. Journal WSEAS Transactions on Business and Economics, 17(17), 769- 774. DOI: 10.37394/23207.2020.17.75

Ben Korda, R. (2017). The Impact of Tax Evasion on Economic Development, Master Thesis, Department of Finance and Accounting, College of Economic, Business and Management Sciences, Abdelhamid Ibn Badis Mostaganem University, Algeria. http://e-biblio.univ-mosta.dz/bitstream/handle/123456789/4019/251.pdf?sequence=1\&isAllowed=y

Dickey, D. A., \& Fuller, W. A. (1979). Distribution of the estimators for autoregressive time series with a unit root. Journal of the American statistical association, 74(366a), 427-431.

Le, H. T. H., Tuyet, V. T. B., Hanh, C. T. B., \& Do, Q. H. (2020). Factors affecting tax compliance among small-and mediumsized enterprises: Evidence from Vietnam. The Journal of Asian Finance, Economics, and Business, 7(7), 209-217.

Narayan, P. K. (2005). The saving and investment nexus for China: evidence from cointegration tests. Applied economics, 37(17), 1979-1990. 
Nawasrah, A. A. M. (2019). The Impact of Tax Revenues on the Growth of GDP in Jordan for the Period (1992-2017), Master Thesis, College of Economics and Administrative Sciences, Al-Bayt University, https://www.aabu.edu.jo

Nazmi, S., \& Mofleh, K. (2015). The role of tax revenues in supplying the Jordanian general budget with public revenues during the period (2006-2013). Journal of the Islamic University for Economic and Administrative Studies, 23(2).

Nguyen, H. H. (2019). Impact of direct tax and indirect tax on economic growth in Vietnam. The Journal of Asian Finance, Economics and Business (JAFEB), 6(4), 129-137.

Pham, T. M. L., LE, T. T., Troung, T. H. L., \& Tran, M. D. (2020). Determinants Influencing Tax Compliance: The Case of Vietnam. The Journal of Asian Finance, Economics, and Business, 7(2), 65-73.

Pesaran, M. H., \& Shin, Y. (1998). An autoregressive distributed-lag modelling approach to cointegration analysis. Econometric Society Monographs, 31, 371-413.

Shawky, M. A. (2017). Analytical Macroeconomics, Knowledge Facility. Alexandria, Egypt. http://www1.aucegypt.edu/src/macroeconomics

The Central Bank of Jordan during the period (2000-2018). https://www.cbj.gov.jo/

The Jordanian Ministry of Finance during the period (2000-2018). https://mof.gov.jo/en-us/mainpage.aspx

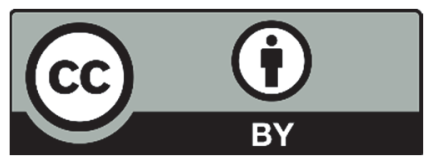

(C) 2021 by the authors; licensee Growing Science, Canada. This is an open access article distributed under the terms and conditions of the Creative Commons Attribution (CC-BY) license (http://creativecommons.org/licenses/by/4.0/). 